\title{
Web Based Application for Competency Test Management of Front Office Manager Occupation
}

\author{
I Gusti agung Sadnyana Putra*, Ni Wayan Wahyu Astuti, I Nyoman Kanca \\ Tourism Department \\ Politeknik Negeri Bali \\ Denpasar, Indonesia \\ *agungsadnyana@pnb.ac.id, wayanwahyuastuti@pnb.ac.id, nyomankanca@pnb.ac.id
}

\begin{abstract}
To find out training graduates who have met the set competency standards, competency certification is conducted through competency tests. In this relation the government established the National Professional Certification Agency to carry out work competency certification which gives a license to the Professional Certification Institute to carry out work competency certification. So far, competency test management is still done manually. Nowadays the progress of information technology, especially in the internet field is very rapid, which also allows its use in the field of management competency testing of labour. This research intends to build a web-based system software for management competency testing of front office manager occupation to support the implementation of competency certification management in Professional Certification Institute. This research was conducted using the Waterfall method, which is a method of sequential and systematic software development consisting of: analysis, design, coding and testing. The results of the implementation of this system will produce complete software that can be used for the management of competency testing for front office manager occupations, consisting of administrative management, participant management, assessor management, competency test implementation, and producing competency recommendations of the assessments to be followed up by National Professional Certification Agency.
\end{abstract}

Keywords-web based management system, competency test, front office manager

\section{INTRODUCTION}

Workforce preparation system in the new paradigm format, there are two principles that form the basis, namely: first, workforce preparation based on user needs (demand driven), and secondly the training process for labour preparation using a competency-based training approach (Competency Based Training / CBT). The development of a workforce preparation system with this new paradigm began in early 2000 which was marked by the signing of a Joint Agreement between the Minister of Manpower, the Minister of National Education, and the Chairperson of the Indonesian Chamber of Commerce. The new paradigm of improving the quality of the workforce rests on three main pillars, namely: (1) work competency standards;
(2) competency-based training; (3) competency certification by an independent institution [1]. Work competency standards are developed in various sectors or professional fields with reference to industry or company needs so that work competency standards can be accepted in the world of work or the labour market, both nationally and internationally. Competency of Indonesian workers are increasingly important ahead of the implementation of the Asean Economic Community (AEC) in 2015.

To find out the training graduates have met the competency standards set, competency certification is done through competency tests. Competency certification is carried out by an independent competency certification body to avoid conflicts of interest between training providers as producers and certification bodies as graduates' quality assurance. The government established National Professional Certification Agency which is obliged to carry out work competency certification. National Professional Certification Agency can grant licenses to Professional Certification Institutions that meet the requirements for implementing work competency certification [2,4]. Professional Certification Institute is an implementing agency for developing competency standards, competency certification and implementing accreditation units for Competency Test Places in a professional field and has technical and administrative responsibilities for the implementation, guidance and development of competency standards and competency certification $[3,5,6]$.

So far the competency management test is still done manually using forms registration of assessments, registration and assignment of assessors, preparation of documents, implementation of exams and reporting result of competency test. Nowadays, the progress of information technology, especially in the internet field, is very rapid, making it possible to utilize this technology in all fields, including in the field of competency testing. With the use of information technology in the form of making a web site, many benefits can be obtained, including easy access the information in place, device and time. These advantages are very meaningful because the management of competency tests becomes easier and faster [7]. 
The research intends to build a web-based software system for front office manager occupation competency testing management to support the implementation of competency certification activities along with supporting activities in the Professional Certification Institute. With the development of this system, it is expected that speed, accuracy, and productivity in Professional Certification Institute will increase $[8,9]$. This research was conducted using the Waterfall method, which is a method of sequential and systematic software development consisting of: analysis, design, coding and testing.

The approach used in system development uses modelling in the planning and system design stages. This information system is implemented with a PHP Triad package, consisting of Apache server, PHP programming language and MySQL as a data storage [10]. The results of the implementation of this system will produce complete software that can be used for the management of competency testing for front office manager occupations, consisting of administrative management, management, assessor management, competency test implementation, and producing competency recommendations for assessments to be followed up by National Professional Certification Agency.

\section{RESEARCH METHODS}

This research is targeted to produce software for competency testing, especially front office manager occupations. This is done using the SDLC (System Development Life Cycle) or Waterfall system or also called a linear sequential system, which is a method of developing sequential and systematic software [11] which consists of the stages namely Analysis, Design, Coding and Testing. This information system development flowchart can be seen in Figure 1.

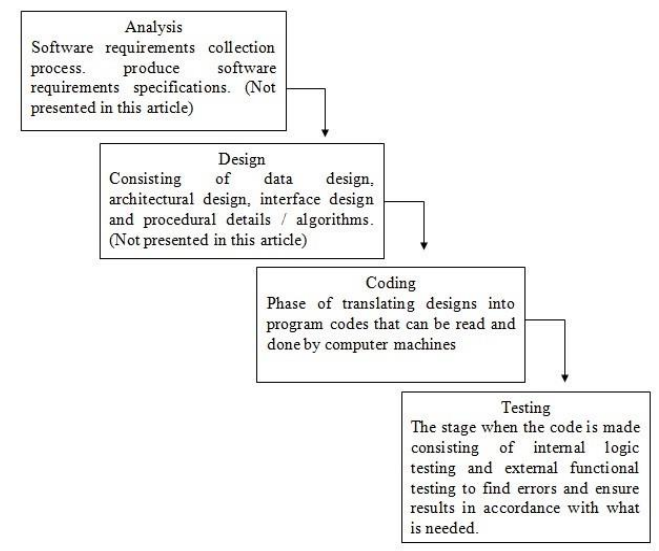

Fig. 1. SDLC information system.

In the analysis phase, the process of collecting software requirements is carried out, such as the information domain, the performance and interfaces required. This stage will produce software requirements specifications presented in the form of data models in the form of ERD (Entity Relationship Diagrams), process models in the form of DFD (Data Flow
Diagrams) and transition models in the form of STD (State Transition Diagrams) [12]. This article only focuses on the final results of research in the form of software products so the results at this stage are not presented in this article.

Design is a multi-step process that follows up the results of the analysis phase, consisting of data design in the form of database structure design, architectural design in the form of program structure design, interface design and procedural details / algorithms that will be applied in the next step which is making program codes. This article only focuses on the final results of research in the form of software products so the results at this stage are not presented in this article.

Coding is the process of translating designs into program codes that can be read and done by computer machines. In this case the coding will use a PHP Triad program consisting of the PHP programming language, MySQL database and Apache server $[10,13,14]$. This stage is the realization of the results of analysis and design in the form of software products and this stage is presented in this article.

Testing is the stage when the code is made which consists of internal logic testing and external functional testing to find errors and ensure the results match what is needed. Testing is done internally by the developers with results as shown in this article.

\section{RESULTS AND DISCUSSION}

Competency Test online application software development using PHP Triad program consisting of PHP programming language, MySQL database and Apache server. Also used is software supporting Dreamweaver to help create the user interface [10-20]. The results of the coding are as follows:

\section{A. Home Page}

The system can be used by providing initial information and a general description of the competency test management modules as shown in Figure 2.

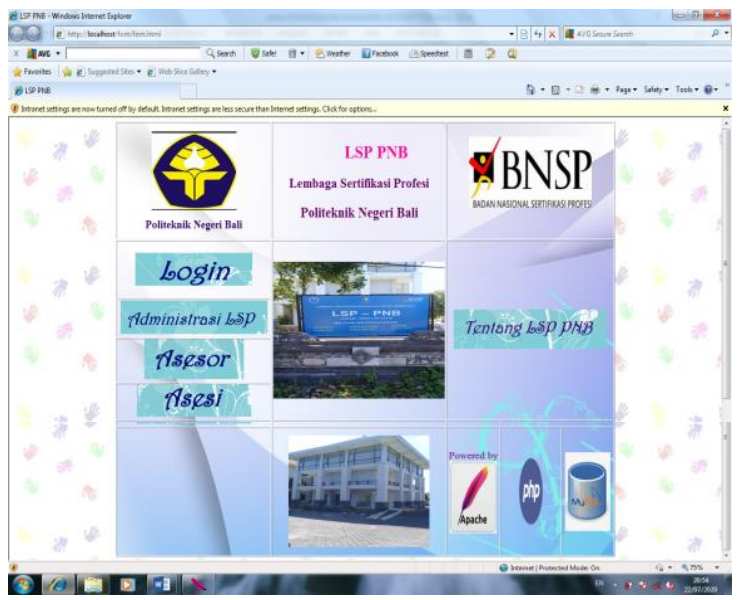

Fig. 2. Home page. 


\section{B. System Elements}

Writing the next program code follows the parts that have been prepared in the form of modules on this home page, namely: Professional Certification Institute Administration, Assessors and Assessions. Also provided a Professional Certification Institute introduction module in the form of "About Professional Certification Institute PNB". These modules can be accessed after going through a user authentication check in the form of checking a username and password, as shown in figure 3.

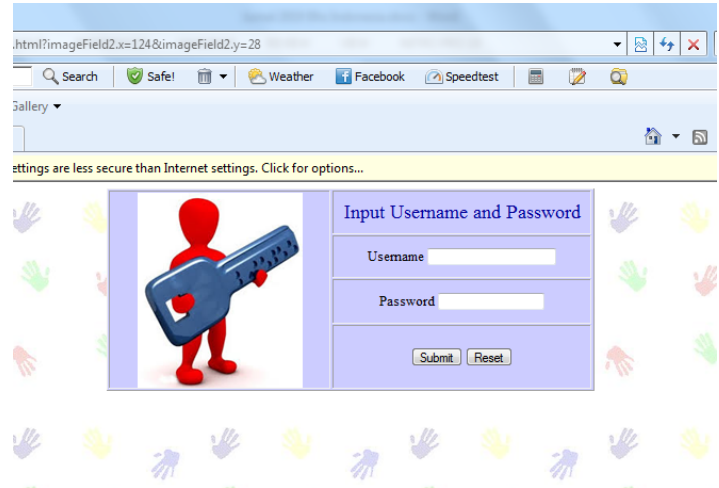

Fig. 3. Input username and password

1) Professional certification institute administration module: This module is provided for personnel who serve as administrative officers on Professional Certification Institute , according to its function, this module provides facilities:

- Management of Participant, consists of: Participant Registration, Assesse Data Edit, View Participant Data.

- Management of Assessors, consisting of: Registration of Assessors, Edit Data of Assessors, View Data of Assessors.

- Management of Assessment Questions, consisting of: Inputs of Self-Assessment Questions, Inputs of Written Assessment Questions, Inputs of Practice Assessment Questions.

2) Assessors module: This module is provided for personnel who act as assessors at the Professional Certification Institute, which is the person who assesses the results of the competency test conducted by the assessors, according to their function, this module provides facilities:

- Management of Assessors, consisting of: Registration of Assessors, View Data of Assessor and View Data of Participant.

- Assessment Management, consisting of: Assessing Self Assessments, Assessing Written Assessments, Assessing Practical Assessments.

3) Participant module: This module is provided for personnel who carry out competency tests (assessments), according to their function, this module provides facilities:
- Participant Management, consisting of: Participant Registration, Edit Participant Data and View Participant Data.

- Competency Assessment Management, consisting of: carrying out Independent Assessments, Conducting Written Assessments, Conducting Practical Assessments.

4) Module about professional certification institute PNB: This module is an additional module provided to show the existence of Professional Certification Institute PNB which is needed for prospective assessors who will conduct a competency test.

\section{Competency Test Cycle}

The cycle that occurs in the management of competency tests is handled by this system and will be explained in the following stages.

1) Registration of participant: Registration of assessments is the first step in the competency test cycle for a prospective workforce who needs a competency certificate for the desired occupation. Registration of prospective assessors in this system can be done by prospective participant or through Professional Certification Institute administration using the menu "Registration of Participant", as shown in figure 4.

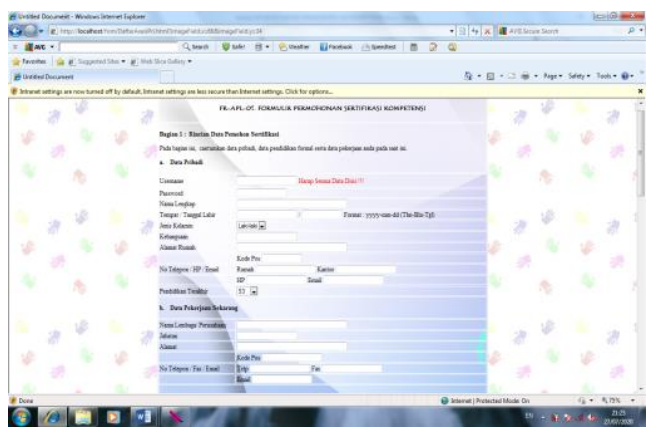

Fig. 4. Participant registration form.

2) Input questions by professional certification institute administration: The questions to be tested are inputted by the Professional Certification Institute administration aiming to make the questions more varied and also maintain its confidentiality. The competency test questions consist of 3 parts, namely: self assessment, written assessment and practical assessment. The question input is done using the menu "Input of Self / Written / Practical Assessment Questions" with the form can be seen in Figure 5. 


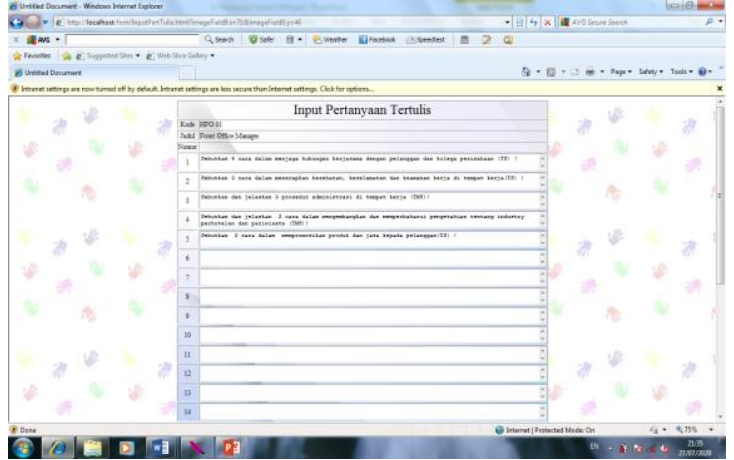

Fig. 5. Form input questions.

3) Implementation of competency test: The implementation of competency tests is a basic part of the competency test management system, carried out by the participants in accordance with the part of the test that must be undertaken. The competency test is carried out by the participant through the menu "Competency Test Implementation" with its form can be seen in Figure 6.

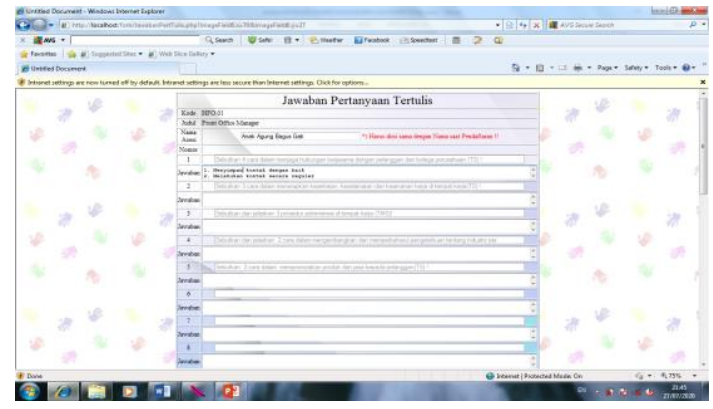

Fig. 6. Implementation of competency test.

4) Competency test assessment: The competency test is assessed by the assigned assessor. The assessment is done using the "Competency Test Assessment" menu in the form that can be seen in Figure 7.

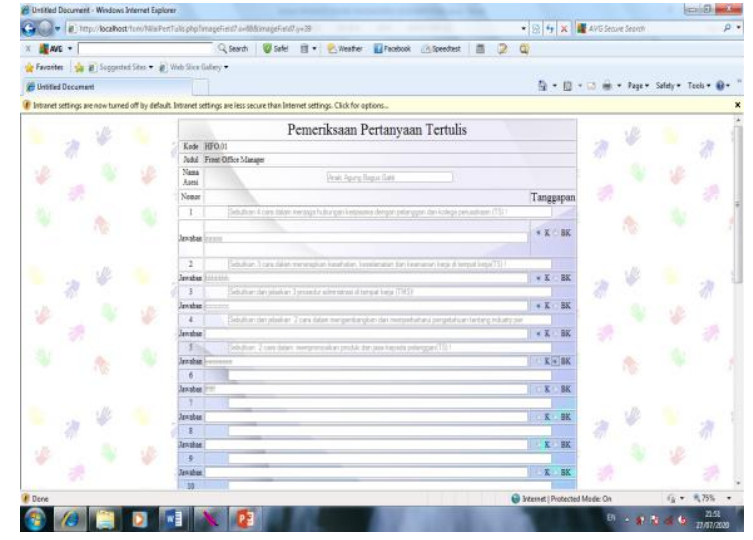

Fig. 7. Assessment of competency test.
5) Competency test assessment results: The results of the competency test assessment are the accumulation of all parts of the competency test that have been passed by Participant, which are then used as a reference for competency recommendations which will be sent and acted upon by National Professional Certification Agency. The form of recommendations can be seen in Figure 8 .

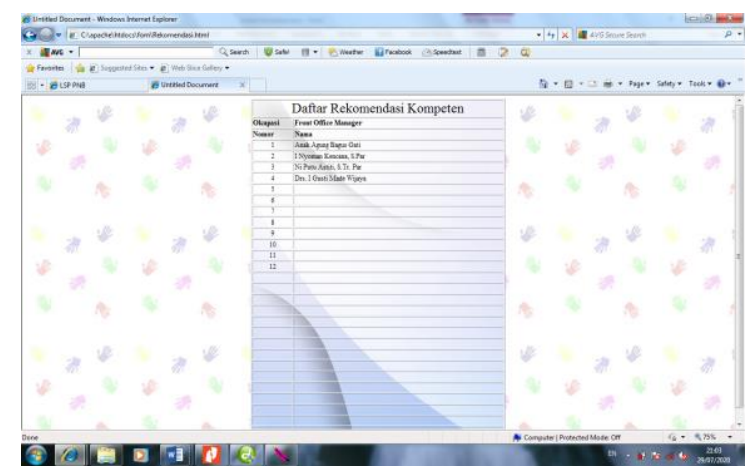

Fig. 8. Competency recommendations.

\section{CONCLUSION}

1. The Web Based Application for Competency Test Management of Front Office Manager Occupation provides modules in accordance with the functions and authorities of the user as follows:

- Professional Certification Institute Administration, i.e. This module is provided for personnel who serve as administrative officers in Professional Certification Institute.

- Assessors Module, this module is provided for personnel who serve as assessors at the Professional Certification Institute, which is the person who assesses the results of competency tests conducted by the assessors.

- Participant Module, this module is provided for personnel who conduct competency tests (assess).

The competency test cycle consists of: registration of assessments by prospective participants, input of questions by the Professional Certification Institute administration, implementation of competency tests by Participants, competency test assessment by assessors and competency recommendations as the final results of competency test assessments, which are then used as a reference for competency recommendations to be sent and acted upon by National Professional Certification Agency.

\section{REFERENCES}

[1] https://National Agency.go.id/informasi?kategori=2

[2] Republic of Indonesia, Government Regulation No. 23 of 2004 concerning the Agency National Professional Certification, 2004. 
[3] L. Erawan, A. Susanto and A. Winarno, "Mika Professional Certification Institute Competency Certification Service Engineering with Information Technology and Web Based Systems," Techno.COM, vol. 16, no. 2, pp. 132-143, 2017.

[4] Republic of Indonesia, Law of the Republic of Indonesia Number 20 of 2003 concerning the National Education System, 2003.

[5] Republic of Indonesia, Government Regulation No. 31 of 2006, concerning the National Job Training System, 2006.

[6] Republic of Indonesia, Decree of the Minister of Manpower and Transmigration No. KEP.96 A / MEN / VI / 2004 Year 2004, concerning Guidelines for the Preparation and Accreditation of Professional Certification Bodies, 2004.

[7] G. Aragon, M.J. Escalona, M. Lang and J.R. Hilera, "An Analysis of Model-Driven Web Engineering Methodologies," International Journal of Innovative Computing, Information and Control, vol. 8, no. 12, pp. 1-10, 2012.

[8] http://academia.edu Accessed on 6 March 2020

[9] http://glosarium.org/arti-front-office-manager Accessed on 6 March 2020

[10] E H. William and L. David, Web Database Application with PHP and MySQL. O'Rilly and Associates Inc, 2012.

[11] P. Pressman, Software Engineering, 7th Edition. McGraw-Hill International Inc, 2015.
[12] H.M. Jogiyanto, Analysis and Design of Information Systems Structured Approach Issue III. Yogyakarta: Andi Offset, 2005.

[13] S. Sutarman, Building Web Applications with PHP and MySQL. Yogyakarta: Publisher Graha Ilmu, 2003.

[14] B. Nugroho, Exercise Create PHP and MySQL Web Applications with Dreamweaver MX. Yogyakarta: Gava Media. 8th ed, 2008.

[15] A. Kadir, Introduction to Information System. Yogyakarta: Andi Offset, 2012

[16] R.Jr. Mc.Leod, Management Information Sistem, 10th Edition. PrenticeHall International Inc, 2015

[17] T. Sutabri, Management Information System. Yogyakarta: Andi Offset, 2005.

[18] S. Korth, Database System Concept, 6th Edition. McGraw-Hill International Inc, 2015.

[19] User Guide and Reference, Version 1.9. Programming and Software Engineering Unit (PST), Institute for Informatics, LudwigMaximilians Universität. München, Germany.

[20] A. Wasowski, D. Truscan and L. Kuzniarz, 8th Nordic Workshop on Model Driven Software Engineering (NW-MODE 2010). Proceedings of the Fourth European Conference on Software Architecture: Companion, vol. 243-244, 2010. 